\title{
Morphology of Female Reproductive Tract of the Predator Podisus nigrispinus (Dallas) (Heteroptera: Pentatomidae) Fed on Different Diets
}

\author{
Walkymário de Paulo Lemos ${ }^{1}$, Francisco de Souza Ramalho ${ }^{2}$, José Eduardo Serrão ${ }^{3 *}$ and \\ José Cola Zanuncio ${ }^{1}$ \\ ${ }^{1}$ Universidade Federal de Viçosa; Departamento de Biologia Animal; 36.571-000; Viçosa - MG - Brazil. \\ ${ }^{2}$ Embrapa Algodão; Unidade de Controle Biológico; C. P. 174; 58.107-720; Campina Grande - PB - Brazil. \\ ${ }^{3}$ Universidade Federal de Viçosa; Departamento de Biologia Geral; 36.571-000; Viçosa - MG - Brazil
}

\begin{abstract}
The morphology of the reproductive tract of Podisus nigrispinus (Dallas) females fed with Alabama argillacea (Hübner) larvae, artificial diet, Tenebrio molitor L. larvae or Musca domestica L. larvae were studied. The reproductive tract of females of this species presented yellow coloration and independent of the diet, each ovary had seven ovarioles joined through terminal filaments and forming a bunch shape structure. The histological data revealed that the ovary of $\mathrm{P}$. nigrispinus was of meroistic telotrophic type, with each individual ovariole divided in a terminal filament, a tropharium (trophic chamber), a vitellarium, and a pedicel. The prey type affected the development and morphometry of these structures. Females of $\mathrm{P}$. nigrispinus fed with $3^{\text {rd }}$ or $5^{\text {th }}$ instar larvae of cotton leafworm (A. argillacea) presented developed ovaries with ovarioles showing a great number of oocytes in advanced stages of development. Females fed with artificial diet presented atrophic ovaries and ovarioles practically without oocytes. Females fed with T. molitor or M. domestica showed ovaries in intermediary stage of development. The central ovariole was longer in females fed with $5^{\text {th }}$ instar larvae of cotton leafworm and shorter in those fed with artificial diet. Most developed oocytes were observed in ovaries of females fed with $5^{\text {th }}$ or $3^{\text {rd }}$ instar larvae of cotton leafworm, and the majority of atrophic oocytes were found in females fed with artificial diet.
\end{abstract}

Key words: Biological control, morphology, ovaries, predator, reproduction

\section{INTRODUCTION}

In Brazil, monocultures in agricultural areas represent ecosystems different from those with natural vegetation or policultures which favors pest species that can adapt to the new conditions what makes necessary to control them (Zanuncio et al., 1993). In this context, the predatory habit of heteropteran species is receiving more attention from researchers as biological control agents of pests.
Podisus nigrispinus (Dallas) (Heteroptera: Pentatomidae) is one of the most studied Asopinae predator in Brazil besides Podisus rostralis (Stäl) (Zanuncio et al., 1994, Matos Neto et al., 1998, Molina-Rugama et al., 1998), Podisus distinctus (Stäl) (Zanuncio et al., 1998, Oliveira et al., 1999), Podisus sculptus Distant (Nascimento et al., 1997), Brontocoris tabidus (Signoret) (Barcelos et al., 1994; Zanuncio et al., 2000) and Supputius cincticeps (Stäl) (Zanuncio et al., 1995, Azevedo and Ramalho 1999a, 1999b, Wanderley

\footnotetext{
Author for correspondence
} 
and Ramalho 1999). Studies on biology (Medeiros et al., 1998, Moreira et al., 1998, Torres et al., 1998), ecology (Zanuncio et al., 1994) and nutrition (Saavedra et al 1996, Lemos et al., 2001) have been developed but little is known about the reproductive tract, internal morphology and histology of $P$. nigrispinus.

The female reproductive system of insects consists of a pair of ovaries in the abdomen above or lateral to the gut, and it is formed by functional units denominated ovarioles associated to tracheae and fat body (Engelmann 1970, Davey 1985, Nijhout 1994, Chapman 1998). The ovarioles are linked to the distal region by terminal filaments connected to the body wall of the insect and, proximally, narrow to a fine tube, the pedicel, which connects to the lateral oviduct. Both lateral oviducts join in a common oviduct (Nijhout 1994, Chapman 1998) which opens into a genital chamber (Chapman 1998). The number of ovarioles per ovary is species-specific and varies from one, as in certain coleopterans, to more than thousands in queen termites (Nijhout 1994) as function of size, life style of the insect and its taxonomic position (Chapman 1998). Each ovary typically contain four to six ovarioles (Nijhout 1994).

The ovaries of insects differ in the way nutrients are available for nourishment of the oocytes (Nijhout 1994) and they can be divided in two types: panoistic and meroistic (Davey 1985, Nijhout 1994, Chapman 1998). Meroistic ovaries are subdivided in telotrophic and polytrophic (Nijhout 1994, Chapman 1998). All Heteropteran species studied showed ovaries of telotrophicmeroistic type (Büning 1994, Simiczyjew et al 1998, Szklarzewicz 1998) with a relatively constant number of ovarioles (Simiczyjew et al 1998). This number is species- and sometimes family-specific but it usually varies from four to seven ovarioles (Büning 1994).

The fecundity of stinkbug predators of the Podisus genus can be negatively affected by unfavorable environmental conditions such as quantity and quality of food consumed during the nymphal and/or adult stage (Wiedenmann and O'Neil 1990, Molina-Rugama et al 1997, 1998). These unfavorable conditions may be responsible for morphological variations of the reproductive organs of these organisms what affect their reproduction.

The aim of this study was to quantify the effect of different preys (Alabama argillacea (Hübner), Tenebrio molitor L., Musca domestica L. and artificial diet) on anatomy and histology of the reproductive tract of females of the predator $P$. nigrispinus.

\section{MATERIALS AND METHODS}

The predator $P$. nigrispinus and the preys $A$. argillacea, T. molitor and $M$. domestica were obtained from mass rearing maintained at UCB/Embrapa Algodão following the procedures describe by Azevedo (1996) and Medeiros (1997). Artificial diet was prepared according to Saavedra et al (1995) and consisted of cattle liver $(60 \mathrm{~g})$, beef ground meat $(60 \mathrm{~g}), 5 \%$ sucrose solution $(18 \mathrm{ml})$, Wesson salts $(60 \mathrm{mg})$, brewer's yeast $(3.0 \mathrm{~g})$, chicken egg yolk (12.0 g), honey (7.2 g), ascorbic acid (30 mg), nipagin (30 $\mathrm{mg})$ and tetracycline (3 mg). P. nigrispinus was maintained during its nymph and adult stages at $25{ }^{\circ} \mathrm{C}$, relative humidity of $60 \pm 10 \%$ and photoperiod of $14 \mathrm{~h}$ light: $10 \mathrm{~h}$ dark with five diets. Diets tested were: $\left(D_{1}\right) 3^{\text {rd }}$ instar larvae of A. argillacea; $\left(D_{2}\right) 5^{\text {th }}$ instar larvae of $A$. argillacea; $\left(\mathrm{D}_{3}\right)$ artificial diet; $\left(\mathrm{D}_{4}\right) 3^{\text {rd }}$ instar larvae of $T$. molitor and $\left(\mathrm{D}_{5}\right) 3^{\text {rd }}$ instar larvae of $M$. domestica.

Newly emerged adults of $P$. nigrispinus were sexed based on their external genitalia appearance and size of body and, then, mated. Females reproductive tracts were dissected and transferred to $4 \%$ paraformaldehyde at phosphate buffer 0.1 $\mathrm{M}, \mathrm{pH}$ 7.4. Morphological characteristics of the reproductive organs of this predator, with each diet tested, were accomplished using the software Image Pro-Plus, version 4.0 (Media Cybernetics). Ten individuals from each diet were analyzed.

The reproductive organs of the females were dehydrated in ethanol series and embedded in historesin (Leica). Sections of $4 \mu \mathrm{m}$ thick were stained with haematoxilyn and eosin. These sections were analyzed and photographed under light microscope. The histological studies were accomplished with three individuals per diet. After the histological sections, comparisons of the histology of these structures were accomplished as function of the different food sources supplied to $P$. nigrispinus.

The effects of different preys on morphometry of reproductive structures of the predator $P$. nigrispinus were analyzed using the PROC GLM procedure (SAS Institute 2000). The means were compared by Student-Newman-Keuls' test $(P=0.05)$. 


\section{RESULTS}

\section{Ovary Morphometry of $\boldsymbol{P}$. nigrispinus}

Observations made under stereomicroscope showed that reproductive tract of mated females of $P$. nigrispinus had yellow coloration placed ventrally in relation to the gut. Independent of the diet each ovary of $P$. nigrispinus had seven ovarioles, joined through the terminal filaments and forming a compact bunch shape structure. The ovarioles resembled long filaments and they were involved by a tracheal network. These ovarioles were connected to one pair of lateral oviducts characterized by a larger diameter than the ovarioles. These oviducts joined to form the common oviduct with similar or slight larger diameter than the lateral oviducts. Although the prey type supplied to $P$. nigrispinus did not affect the number of ovarioles/ovary it caused modifications on development and morphometry of these structures.

Dead females of $P$. nigrispinus fed with $3^{\text {rd }}$ or $5^{\text {th }}$ instar larvae of the cotton leaf worm showed well developed ovarioles with ovarioles containing high number of mature oocytes (Figs. 1, 2). These oocytes showed well characterized chorion and completely developed micropyles prolongations (Fig. 3). The oocytes, in this developmental stage, were generally placed in the calyx region, near to the lateral oviduct. Females fed with artificial diet presented atrophic ovaries and ovarioles almost without oocytes (Fig. 4). The calyx of females that received artificial diet presented ovarioles with compacted proximal ends (Fig. 4). Females fed on T. molitor (Fig. 5) or M. domestica (Fig. 6) showed ovaries at intermediary development stage and their ovarioles with oocytes in different maturation stages. Most of the ovarioles of this predator that fed on these preys did not have completely developed oocytes (Figs. 5, 6).

The interactions of prey type with position of the central ovariole in the ovary (left and right) and of more developed oocytes in the ovary (left and right) of mated females of the predator $P$. nigrispinus was studied. They showed that prey type did not affect the length of the central ovariole $(F=0.59 ; \mathrm{df}=4,81 ; P=0.6728)$ or the more developed oocyte $(F=0.77 ; \mathrm{df}=4,81 ; P=$ 0.5478).
The prey type supplied to $P$. nigrispinus affected the length of the central ovariole and of most developed oocytes. The length of the central ovariole of this predator was longer in females fed with $5^{\text {th }}$ instar larvae of the cotton leaf worm (7.02 $\pm 0.21 \mathrm{~mm})(F=49.10 ; \mathrm{df}=4,81 ; P<0.0001)$ and shorter in those fed with artificial diet $(2.60 \pm 0.16$ $\mathrm{mm}$ ) (Fig. 7A). More developed oocytes were observed in ovaries of females of $P$. nigrispinus fed with $5^{\text {th }}$ instar $(1.08 \pm 0.03 \mathrm{~mm})$ or $3^{\text {rd }}$ instar $(0.99 \pm 0.03 \mathrm{~mm})$ larvae of the cotton leaf worm $(F=39.27 ; \mathrm{df}=4,81 ; P<0.0001)$ while the most atrophic ones were found in females fed with artificial diet $(0.25 \pm 0.03 \mathrm{~mm})$ (Fig. 7B).

\section{Ovary Histology of $\boldsymbol{P}$. nigrispinus}

Histological studies showed that the ovary of $P$. nigrispinus was of the telotrophic-meroistic type, and each ovary was covered by a sheath of epithelial cells and a muscle layer, the peritoneal sheath. Each ovariole was divided in a terminal filament, a tropharium (trophic chamber), a vitellarium, and a pedicel. The terminal filament was built with spindle-shaped cells, oriented perpendicularly to the long ovariole axis. The apical part of each ovariole was formed by a germarium region with cells in differentiation process. The tropharium was a trophic chamber, i. e., nurse cells surrounding the central part of the ovariole, which is named nutritive cord which is a component of the nutrient transport system between the trophocytes and oocytes (Fig.8).

The other region of ovarioles was constituted by vitellarium where the development of vitellogenesis and the oocytes occurs. This region was characterized by oocytes in different developmental stages and in linear arrangement (Fig. 9). Each oocyte was surrounded by a single layer of follicular cells. This surrounding layer was interrupted at the communication point between the nutritive cord and the oocyte (Fig. 10). When the oocyte was located near the germarium region and at early developmental stage, the follicular cells were flattened and compact. However, when the oocytes were developing, these cells become cubic and less compacted (Fig. 11). 

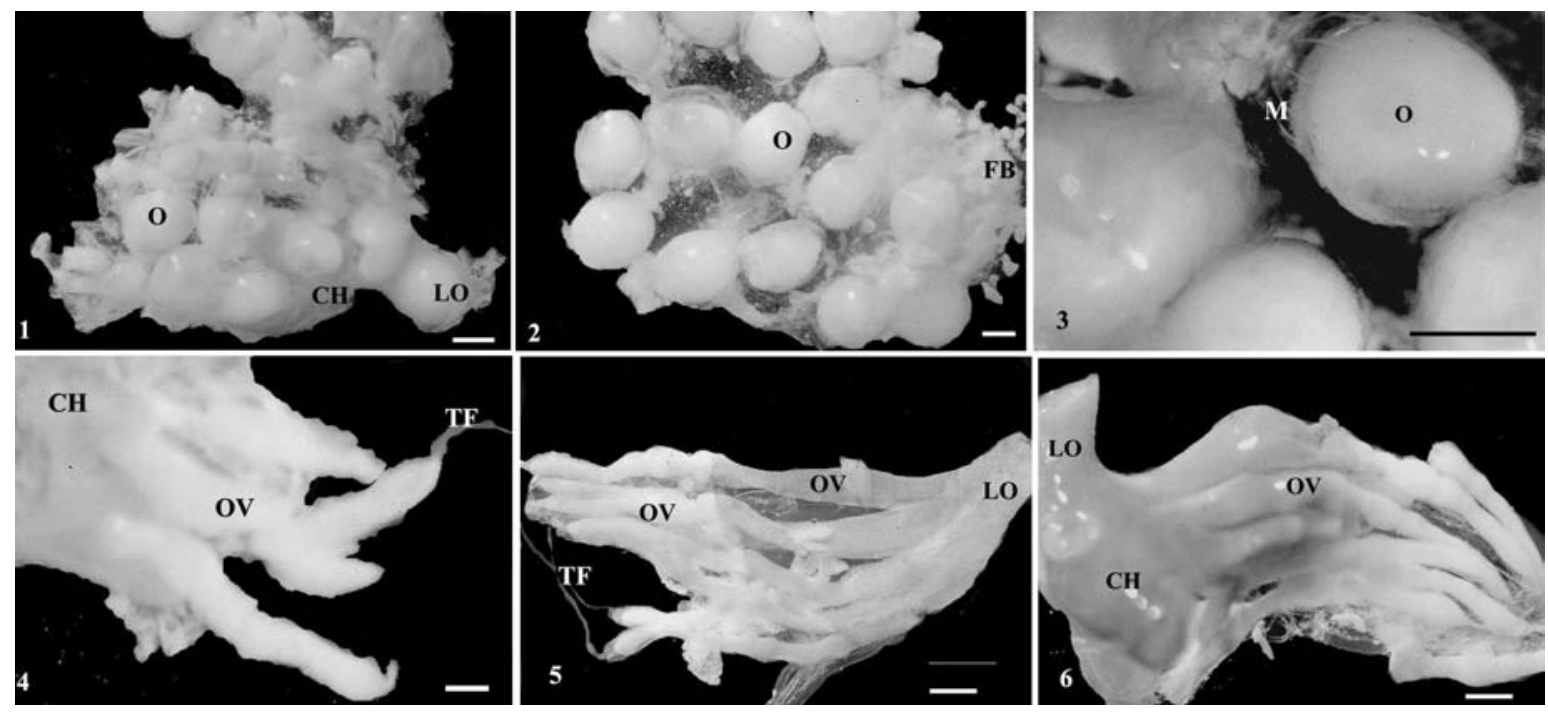

Figures 1-6 - Female reproductive system of Podisus nigrispinus fed on different preys. 1-2. Partial view of predator ovaries fed on $3^{\text {rd }}$ or $5^{\text {th }}$ instar larvae of cotton leafworm showing high development degree. 3. Morphological details of oocytes. 4. General view of ovaries of $P$. nigrispinus fed with artificial diet, (5) T. molitor or (6) M. domestica, showing differences on the development. $\mathrm{CH}$ - chalice region; FB- fat body; LO- lateral oviduct; M- micropyles prolongations; O- oocyte; OV- ovariole; TF- terminal filaments. Bars $=100 \mathrm{~mm}$.

Developed oocytes showed increasing volume and yolk quantity. In advanced maturation stages, the nutritive cords broke. The follicular cells started to secrete the eggshell when the oocytes were completely developed. The prey type that $P$. nigrispinus received influenced the degree of development of ovaries $(F=49.10 ; \mathrm{df}=4,81$; $P<0.0001)$. Females fed on $3^{\text {rd }}$ or $5^{\text {th }}$ instar larvae of cotton leaf worm presented high quantity of mature oocytes . The histological sections of these structures showed well defined areas of follicular cells surrounding the oocytes. It was not possible to verify characteristics of cell death in follicular cells of the ovarioles of females fed with $3^{\text {rd }}$ or $5^{\text {th }}$ instar larvae of the cotton leaf worm. A differentiation process of these cells was found at the beginning of the formation of micropyle prolongations that were visible in completely developed eggs (Fig. 12). This showed the presence of the chorion of eggs surrounded by completely developed eggshell (choriogenesis process completed) and yolk (Fig. 12).

Unlike that found for females of this predator fed with $5^{\text {th }}$ instar larvae of cotton leaf worm, females fed on $3^{\text {rd }}$ instar larvae of this prey had ovarioles without mature oocytes. Females of predator fed $T$. molitor showed few developed oocytes and clear differentiation of several regions of the ovariole (Fig. 16). The oocytes in more advanced development stage showed more compact follicular cells surrounding them. The follicular cell thick and space between them increased with oocyte growth. Most of the oocytes inside the ovariole did not present evidence of chorion formation or cell death.

The ovarioles of female fed on house fly larvae presented poor development and low number of oocytes in early development stage. Predators fed with this prey showed a great part of the ovarioles without oocytes with ovariole walls folded (Fig. 13). No mature oocyte (presence of chorion and micropyle prolongations) inside the ovarioles and evidence of cell death were found in these structures. Females fed with artificial diet presented less developed ovarioles and a reduced number of oocytes, all in early development stage. Some ovarioles were atrophic (Fig. 14) and with high degree of cell death. Cells of the germarium region and the follicular cells presented picnotic nuclei (Fig. 15). This was not observed in ovaries of females fed with the other diets what shows the process of cell degeneration in the structures for females fed with artificial diet. 

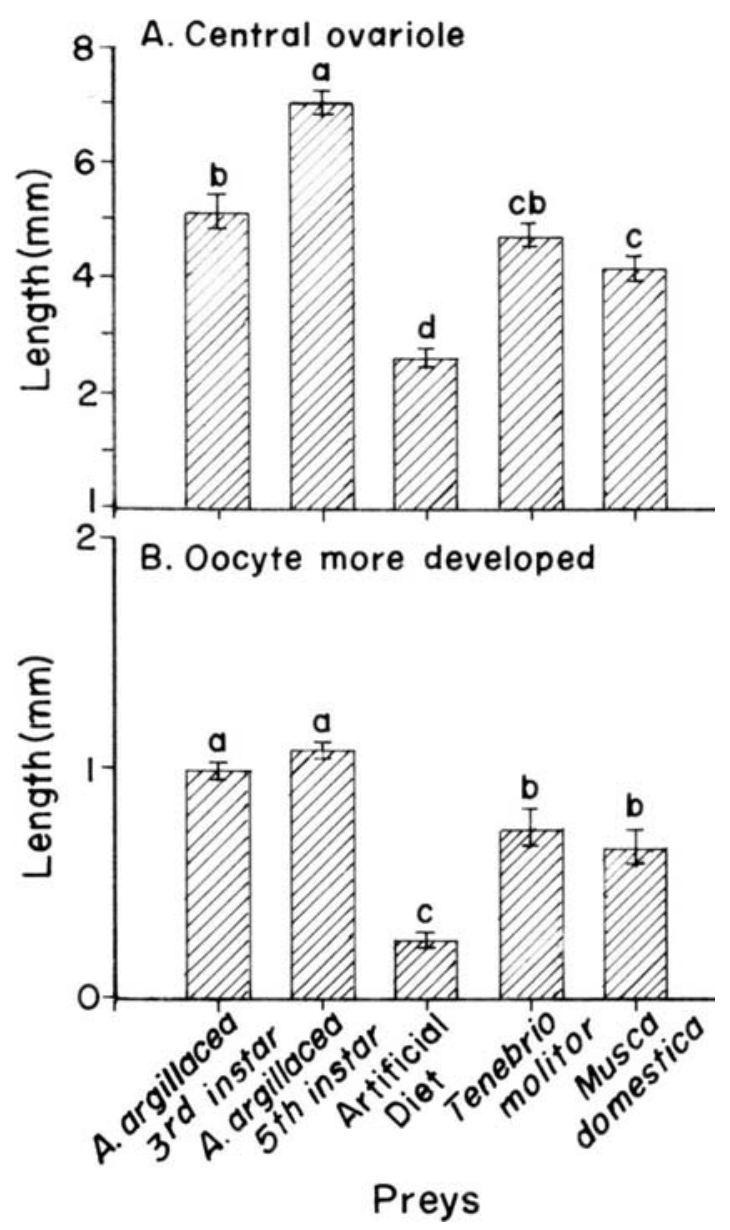

Figure 7 - (A) Influence of the prey on length of central ovariole and (B) more developed oocyte of Podisus nigrispinus, at $25^{\circ} \mathrm{C}, 60 \pm 10 \%$ relative humidity and photoperiod 14L:10D. Student-Newman-Keuls test: for each variable, means followed by the same letter are not significantly different $(\mathrm{P}=0,05)$. Bars indicate the standard error.

\section{DISCUSSION}

Few researches have studied the anatomy and histology of the internal gonads of heteropterans, especially regarding the effects of the prey on these structures. However, when compared to other insects, the ovaries of these organisms are more difficult to be understood (Büning 1994). The internal gonad of $P$. nigrispinus females is similar to those of other stinkbugs but anatomical and histological variations as function of the prey supplied were found. Females of $P$. nigrispinus submitted to different diets showed ovarioles with oocytes at different development stages, which demonstrate the effect of the prey on the development of these structures. Büning (1994) has pointed out that each ovariole inside the ovary presents similar development stage with no development gradients between them. Our results differ from this because females of $P$. nigrispinus fed with $T$. molitor, $M$. domestica or artificial diet presented few oocytes at different development stages inside the ovarioles, resulting in ovarioles with development gradients inside the same ovary. The smallest number of oocytes per ovariole was found in ovaries of females fed with artificial diet. Adams (2000) reported that females of the pentatomid predator Perillus bioculatus (F.) fed with artificial diet showed reduction on the number of gonotrophic cycles per ovariole up to 
50\%. Similar tendency has been observed for females of $P$. nigrispinus fed on artificial diet what may explain the low rate of fecundity of this predator fed with this diet. However, females of $P$. nigrispinus fed with $3^{\text {rd }}$ or $5^{\text {th }}$ instar larvae of the cotton leaf worm showed well developed ovarioles and with high number of oocytes in advanced stage of development, chorion well characterized and the micropyle prolongations developed. These characteristics of $P$. nigrispinus females fed with these diets suggested that they were able to produce eggs during their entire lifespan development what could explain the high fecundity of insects fed with these preys (Lemos (2001). Similar results were observed for females of P. nigrispinus fed with Galleria mellonella L. and Spodoptera exigua (Hübner) with oviposition during their entire lifespan and with eggs into ovaries after death (De Clercq and Degheele 1990a, 1990b). Thus, $3^{\text {rd }}$ or $5^{\text {th }}$ instar larvae of cotton leaf worm were nutritionally suitable for development of reproductive structures of this predator. This is similar to that found by Adams (2000) that females needed adequate diets to synthesize sufficient vitellogenine to guarantee a high fecundity level.

The central ovariole and the most developed oocyte were larger in females fed with $3^{\text {rd }}$ or $5^{\text {th }}$ instar larvae of cotton leaf worm and shorter in those fed with artificial diet. Highest reproductive rates were found for females of this predator with developed reproductive structures what show that the quality and quantity of food during the nymphal stage can affect body size and reproductive systems of adults (Lin and Winston 1998). Thus, it could be possible that proteins present in $5^{\text {th }}$ instar larvae of cotton leaf worm were suitable to promote a high ovarian activation in females of $P$. nigrispinus, or that this predator presents proteolytic enzymes able to efficiently breakdown proteins present in these larvae. Larger ovarian development of Apis mellifera (L.) fed with royal jelly than pollen was not due to the protein content of these diets but to the inability of the bees to digest proteins of pollen grains because they lack appropriate proteolytic enzymes (Lin and Winston 1998).

Ovaries of $P$. nigrispinus were of telotrophicmeroistic type such as found for other heteropteran (Büning 1994, Simiczyjew et al 1998, Szklarzewicz 1998 and Adams 2000). The seven ovarioles/ovary found is similar to that reported by Büning (1994) who pointed out that the number of ovarioles per ovary varied from four to seven in this group of insect. The number of ovarioles per ovary in insects is species-specific and varies from one in certain coleopterans, to more than thousands, as in termite queens (Nijhout 1994, Chapman 1998) and to some extent this number can determine the reproductive capacity of a species (Elgelmann 1970).

The ovaries of $P$. nigrispinus were similar to those described by Büning (1994), Chapman (1998), Simiczyjew et al (1998), and Szklarzewicz (1998) for other species of stinkbugs. The general structure of heteropteran ovarioles was uniform, showing differences only in the tropharium organization. Morphological (Simiczyjew et al 1998, Szklarzewicz 1998), structural (Ksiazkiewicz-Kapralska 1985, 1991) and histochemical studies (Huebner and Anderson 1972, Choi and Nagl 1976, Huebner 1981) have shown that heteropteran tropharium differed significantly in primitive and more advanced species. Consequently, the results of comparative analyses of the tropharium architecture could be used for phylogenetic considerations (Simiczyjew et al 1998, Szklarzewicz 1998).

The ovarioles of $P$. nigrispinus contained a linear series of oocytes in successive stages of development, where the most developed moved forward in proximal position and more distant from the germarium. This fact was more evident in stinkbugs fed with $3^{\text {rd }}$ or $5^{\text {th }}$ instar larvae of cotton leaf worm which presented higher number of oocytes per ovary. Nijhout (1994) defined that the process of eggs development in the ovariole can be divided in three stages: first, the oocyte underwent a period of previtellogenic growth with accumulation of proteins, carbohydrates and other nutrients. During this stage, the mRNA and the ribonucleoproteins were transported to oocytes through a gradient of electric potential (Chapman 1998). Then, followed a period of vitellogenesis, during which the oocytes specifically accumulated vitellogenine from the haemolymph. The final stage was choriogenesis when the proteinaceous eggshell (chorion) is secreted around the oocyte. The last two stages of oocyte maturation required a special activity of the follicular cells that were responsible for controlling the access of proteins and nutrients to the oocytes for secretion of the chorion. 


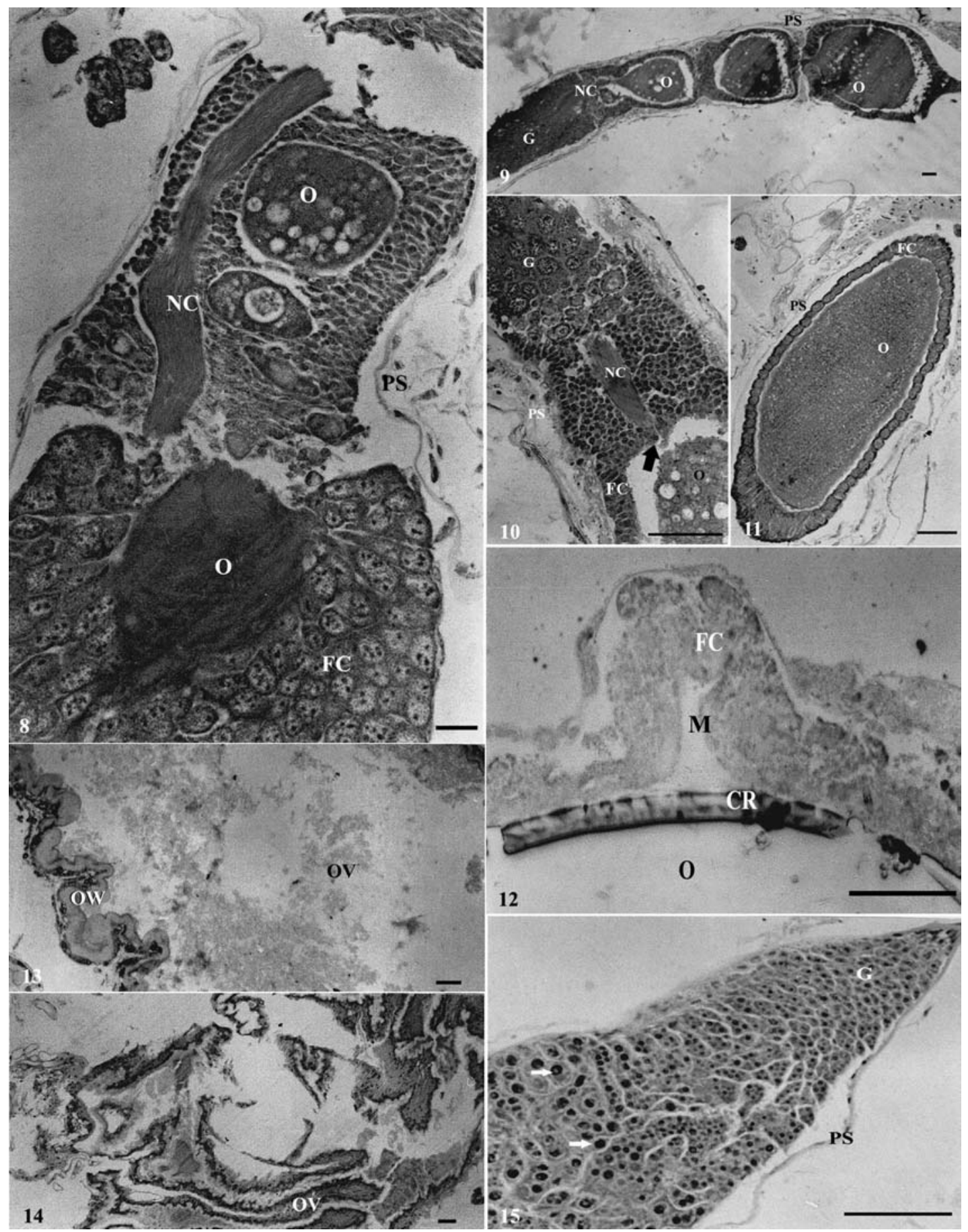

Figures 8-15 - Longitudinal section of Podisus nigrispinus ovarioles. 8. Tropharium region and the nutritive cord linking to the oocytes in ovariole of $P$. nigrispinus fed with Tenebrio molitor larvae. 9. General view of oocytes in different development stages and with linear arrangement in P. nigrispinus fed with T. molitor larvae. 10-11. Details of the follicular cells that surround the oocytes in different development stages, showing the interruption of follicular epithelium near the nutritive cord (arrow) in P. nigrispinus fed with T. molitor larvae. 12. Ovarioles of $P$. nigrispinus fed on 3rd or 5th instar larvae of Alabama argillacea showing the egg chorion well developed (CR) and the beginning of the process of differentiation of follicular cells to formation of micropyles prolongation (M). 
13. Absence of oocytes inside the ovariole of $P$. nigrispinus fed on Musca domestica larvae and ovariole walls forming invaginations. 14-15. Ovarioles of $P$. nigrispinus fed on artificial diet presenting an atrophic development (14) and high degree of cells with picnotic nucleus (arrows). FC - follicular cells; $\mathrm{G}$ - germarium; NC - nutritive cord; $\mathrm{O}$ oocyte; OV- ovariole; OW- ovariole wall; PS - peritoneal sheath. Bars $=50 \mu \mathrm{m}$.

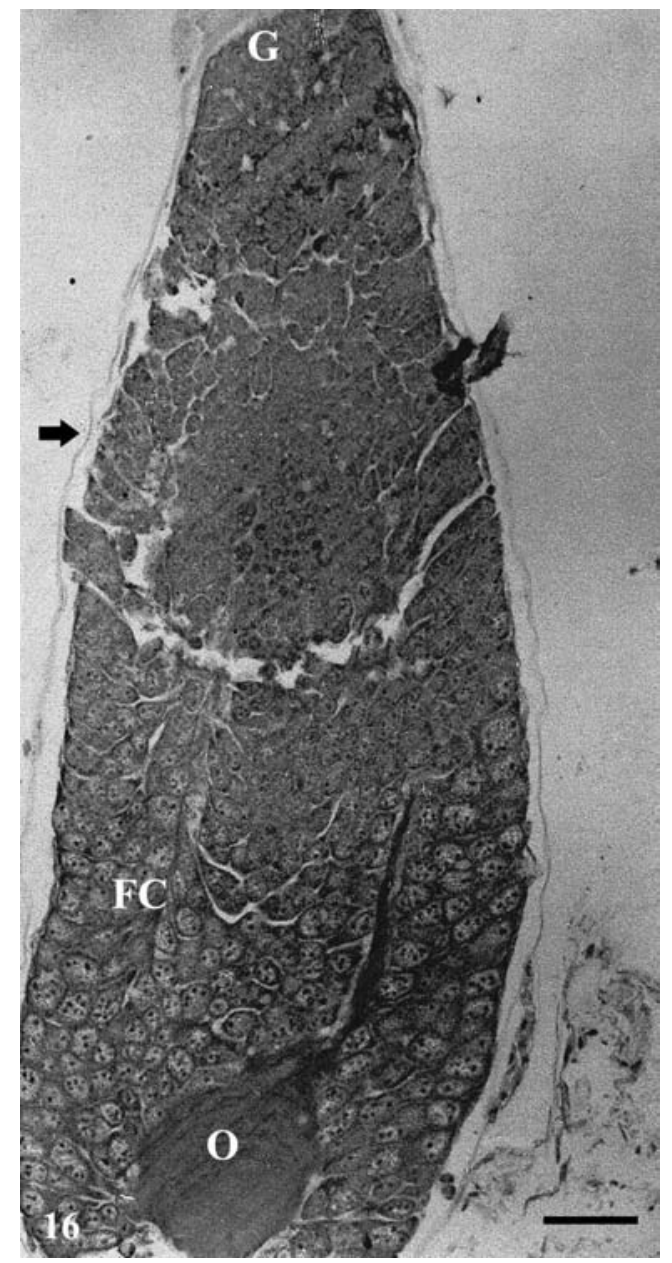

Figure 16 - Longitudinal sections of ovarioles of Podisus nigrispinus fed on Tenebrio molitor larvae showing the presence of oocytes few developed (O). FC follicular cells; G - germanium; arrow peritoneal sheath. $\mathrm{Bar}=50 \mu \mathrm{m}$.

The prey type influenced the development of oocytes inside the ovarioles of to P. nigrispinus. Females fed on $3^{\text {rd }}$ or $5^{\text {th }}$ instar larvae of cotton leaf worm always presented mature oocytes. This confirmed that the process of egg formation in these insects was already completed and that they were able to reproduce during their entire life span. However, when fed with artificial diet, the choriogenesis process was probably affected, because we could not observe any mature oocytes inside the ovarioles in dead $P$. nigrispinus females. This fact may explain the low fecundity of this predator when fed with artificial diet.

The ovarioles of $P$. nigrispinus females fed with artificial diet presented advanced degree of cell death what could be associated with the nutritive inadequacy of this diet. The degeneration of follicular cells could occur by nutritional stress, delaying or blocking oviposition and it represents a way to recycle nutrients found in the oocytes. Thus, $P$. nigrispinus females fed with $3^{\text {rd }}$ or $5^{\text {th }}$ instar larvae of the cotton leaf worm had well developed ovaries with high amount of mature oocytes. It demonstrated that these preys were the most suitable to promote a better reproductive response in this predator.

\section{ACKNOWLEDGEMENTS}

We express our appreciation to the personnel of the Biological Control Unit/Embrapa Algodão and of Departments of General Biology and Animal Biology (Federal University of Viçosa). This work was supported by funds from the CAPES, CNPq and FAPEMIG.

\section{RESUMO}

Este estudo apresenta a morfologia do sistema reprodutor feminino de Podisus nigrispinus (Dallas) alimentado com larvas de Alabama argillacea (Hübner), Musca domestica L. e de Tenebrio molitor L. ou dieta artificial. As gônadas internas desse predador apresentaram coloração amarelada e, independente da dieta, cada ovário apresentou sete ovaríolos unidos pelos filamentos terminais em uma estrutura em forma de cacho. A análise histológica revelou que o ovário de $P$. nigrispinus é do tipo meroístico telotrófico com cada ovaríolo dividido morfologicamente em filamento terminal, trofário (câmara nutridora), 
vitelário e pedicelo. A dieta recebida por esse predador alterou o desenvolvimento e a morfometria de seus ovários. Fêmeas de $P$. nigrispinus alimentadas com larvas de terceiro ou quinto estádio de A. argillacea apresentaram ovários desenvolvidos com grande número de ovócitos em estágio avançado de desenvolvimento nos ovaríolos. Fêmeas com dieta artificial apresentaram ovários atrofiados e ovaríolos, praticamente, sem ovócitos em seu interior enquanto aquelas alimentadas com larvas de $T$. molitor ou $M$. domestica tiveram ovários em estágios intermediários de desenvolvimento. O comprimento do ovaríolo central foi maior em fêmeas alimentadas com larvas de quinto estádio de A. argillacea e menor naquelas com dieta artificial. Ovócitos em estágios mais avançados de desenvolvimento foram observados para fêmeas alimentadas com larvas de terceiro ou quinto estádios de $A$. argillacea, enquanto ovócitos atrofiados foram observados para aquelas com dieta artificial.

\section{REFERENCES}

Adams, T. S. (2000), Effect of diet and mating status on ovarian development in a predaceous stinkbug Perillus bioculatus (Hemiptera:Pentatomidae). Ann. Entomol. Soc. Am., 93, 529-535.

Azevedo, F. R. (1996), Efeitos da temperatura e defesa da presa no consumo e utilização de larvas de Tenebrio molitor Linné por ninfas do predador Supputius cincticeps (Stäl, 1860) (Hemiptera: Pentatomidae). Msc Thesis, Universidade Federal Rural de Pernambuco, Recife, Pernambuco, Brasil.

Azevedo, F. R. and Ramalho, F. S. (1999a), Efeitos da temperatura e da defesa da presa no consumo pelo predador Supputius cincticeps (Stäl) (Heteroptera: Pentatomidae). Pesq. Agrop. Bras., 34, 165-171.

Azevedo, F.R. and Ramalho, F.S. (1999b), Impacto da temperatura e da defesa da presa na utilização de Tenebrio molitor L. por ninfas do predador Supputius cincticeps (Heteroptera: Pentatomidae). An. Soc. Entomol. Brasil, 28, 111-119.

Barcelos, J. A. V.; Zanuncio, J. C.; Oliveira, A. C. and Nascimento, E. C. (1994), Performance em duas dietas e descrição dos adultos de Brontocoris tabidus (Signoret) (Heteroptera: Pentatomidae). An. Soc. Entomol. Brasil, 23, 519-524.

Büning, J. (1994), The ovary of ectognatha, the Insect s. stir., In: Büning, J. (Ed.). The Insect Ovary Ultrastructure, Previtellogenic Growth and Evolution. Chapman and Hall, London, UK. pp. 31-324.
Chapman, R. F. (1998), Reproductive system: female. In: Chapman, R. F. (Ed.). The Insects: Structure and Function. Cambridge University, Cambridge, UK. pp. 295-324.

Choi, W. C.and Nagl, W. (1976), Electron microscopic study on the differentiation and development of trophocytes and oocytes in Geris nanas (Heteroptera). Cytobios, 17, 47-62.

Davey, K. G. (1985), The female reproductive tract. In: Kerkut, G. A. and Gilbert, L. I. (Eds.). Comprehensive Insect Physiology, Biochemistry and Pharmacology. Pergamon Press, Oxford, UK. pp. 15-36.

De Clercq, P.and Degheele, D. (1990a), Description and life history of the predatory bug Podisus sagitta (Fab.) (Hemiptera: Pentatomidae). Can. Entomol., 122, 1149-1156.

De Clercq, P. and Degheele, D. (1990b), Effects of the temperature and relative humidity on the reproduction of the predatory bug Podisus sagitta (Fab.) (Heteroptera: Pentatomidae). Med. Fac. Landbouww. Univ. Gent, 55, 439-443.

Engelmann, F. (1970), Factors that affect egg production and fecundity. In: Engelmann, F. (Ed.). The Physiology of Insects Reproduction. Pergamon Press, Oxford, UK. pp. 107-142.

Huebner, E. (1981), Nurce cell-oocyte interaction in the telotrophic ovarioles of an insect, Rhodnius prolixus. Tissue Cell, 13, 105-125.

Huebner, E. and Anderson, E. (1972), A cytological study of the ovary of Rhodnius prolixus. III. Cytoarchitecture and development of the trophic chamber. J. Morphol., 138, 1-40.

Ksiazkiewicz-Kapralska, M. (1985), Organization of the trophic chamber of homopteran insects. 1: Cercopidae: Cicadomorpha. Cytobios, 42, 133-145.

Ksiazkiewicz-Kapralska, M. (1991), Organization of the trophic chamber of homopteran insects. 2: Membracidae: Cicadomorpha. Cytobios, 66, 113-119.

Lemos, W. P. (2001), Efeito de diferentes presas no desenvolvimento das estruturas reprodutivas e na reprodução do predador Podisus nigrispinus (Heteroptera: Pentatomidae). MSc Thesis, Universidade Federal de Viçosa, Viçosa, Minas Gerais, Brazil.

Lemos, W. P.; Medeiros, R. S.; Ramalho, F. S. and Zanuncio, J. C. (2001), Effects of plant feeding on the development, survival, and reproduction of Podisus nigrispinus (Dallas) (Heteroptera: Pentatomidae). Intern. J. Pest Manag., 27, 89-93.

Lin, H. and Winston, M. L. (1998), The role of nutrition and temperature in the ovarian development of the worker honey bee (Apis mellifera). Can. Entomol., 130, 883-891.

Matos Neto, F. C.; Zanuncio, J. C.; Freitas, L. C. and Gomes, B. M. R. (1998), Nymphal development of the predator Podisus rostralis (Heteroptera: Pentatomidae) fed with three alternative prey. Brenesia, 50, 72-77. 
Medeiros, R. S. (1997), Efeitos da temperatura na biologia de Podisus nigrispinus (Dallas, 1851) (Hemiptera: Pentatomidae), predador do curuquerêdo-algodoeiro. BSc Thesis, Universidade Federal da Paraíba, Areia, Paraíba, Brazil.

Medeiros, R. S.; Lemos, W. P. and Ramalho, F. S. (1998), Efeitos da temperatura no desenvolvimento de Podisus nigrispinus (Dallas) (Heteroptera, Pentatomidae), predador do curuquerê-doalgodoeiro (Lepidoptera, Noctuidae). Revta Bras. Ent., 42, 121-130.

Molina-Rugama, A. J.; Zanuncio, J. C.; Torres, J. B. and Zanuncio, T. V. (1997), Longevidad y fecundidad de Podisus nigrispinus (Heteroptera: Pentatomidae) alimentado com Musca domestica (Diptera: Muscidae) y frijol. Revta Biol. Trop., 45, 1125-1130.

Molina-Rugama, A. J.; Zanuncio, J. C.; Zanuncio, T. V. and Oliveira, M. L. R. (1998), Reproductive strategy of Podisus rostralis (Stäl) (Heteroptera: Pentatomidae) females under different feeding intervals. Bioc. Sci. Technol., 8, 583-588.

Moreira, L. A.; Zanuncio, J. C. and Molina-Rugama, A. J. (1998), Dados biológicos de Podisus nigrispinus (Dallas) alimentado com a lagarta do maracujazeiro Dione juno juno (Cramer). An. Soc. Entomol. Brasil, 27, 645-647.

Nascimento, E. C.; Zanuncio, J. C.; Picanço, M. C and Zanuncio, T. V. (1997), Desenvolvimento de Podisus sculptus Distant, 1889 (Heteroptera: Pentatomidae) em Bombyx mori (Lepidoptera: Bombycidae) e Tenebrio molitor (Coleoptera: Tenebrionidae). Revta Bras. Biol., 57, 195-201.

Nijhout, H. F. (1994), Reproduction, In: Nijhout, H. F. (Ed.). Insect Hormone. Princeton University, Princeton. pp. 142-159.

Oliveira, H. N.; Zanuncio, J. C.; Sossai, M. F. and Pratissoli, D. (1999), Body weight increment of Podisus distinctus (Stäl) (Heteroptera: Pentatomidae), fed on Tenebrio molitor L. (Coleoptera: Tenebrionidae) or Musca domestica L. (Diptera: Muscidae). Brenesia, 51, 77-83.

Saavedra, J. L. D.; Zanuncio, J. C.; Sediyama, C. S. and Zanuncio, T. V. (1995), Fecundidad y fertilidad del predador Podisus nigrispinus (Dallas) (Heteroptera: Pentatomidae) en cuatro dietas artificiales. Turrialba, 45, 70-75.

Saavedra, J. L. D.; Zanuncio, J. C.; Zanuncio, T. V. and Santos, G. P. (1996), Desarrollo ninfal de Podisus nigrispinus (Heteroptera: Pentatomidae) en alimentacion mixta de dieta artificial y larvas de Musca domestica (Diptera: Muscidae). Brenesia, 46, 177-182.

SAS Institute (2000), User's manual, version 8.1 ed. SAS Institute, Cary, NC.

Simiczyjew, B.; Ogorzalek, A. and Stys, P. (1998), Heteroptera ovaries: variations on the theme. Folia Histochem. Cytobiol., 36, 147-156.
Szklarzewicz, T. (1998), The ovaries of scale insects (Hemiptera, Coccinea). Morphology and phylogenetic conclusions. Folia Histochem. Cytobiol., 36, 157-165.

Torres, J. B.; Zanuncio, J. C. and Oliveira, H. N. (1998), Nymphal development and adult reproduction of the stinkbug predator Podisus nigrispinus (Het., Pentatomidae) under fluctuating temperatures. J. Appl. Entomol., 122, 509-514.

Wanderley, M. J. A. and Ramalho, F. S. (1999), Efeitos da temperatura no desenvolvimento de Supputius cincticeps (Stäl) (Heteroptera: Pentatomidae) alimentado com larvas de Musca domestica L. An. Soc. Entomol. Brasil, 28, 121-129.

Wiedenmamm, R. N. and ONNeil. R. J. (1990), Effects of low rates of predation on selected life-history characteristics of Podisus maculiventris (Say) (Heteroptera: Pentatomidae). Can. Entomol., 122, 271-283.

Zanuncio, J. C.; Nascimento, E. C.; Zanuncio, T. V. and Cruz A. P. (1993), Descrição das ninfas do predador Podisus sculptus Distant, 1889 (Hemiptera: Pentatomidae). Revta Bras. Ent., 37, 403-408.

Zanuncio, J. C.; Alves, J. B.; Zanuncio, T. V. and Garcia, J. F. (1994), Hemipterous predators of eucalypt desfoliators caterpillars. For. Ecol. Manag., 65, 65-73.

Zanuncio, T. V.; Zanuncio, J. C.; Vilela E. F. and Santos, G. P. (1995), Biologia de Supputius cincticeps Stäl (Hemiptera, Pentatomidae) criado em larvas de Tenebrio molitor (Coleoptera, Tenebrionidae) e de Musca domestica (Diptera, Muscidae). Rev. Bras. Ent., 39, 183-187.

Zanuncio, T. V.; Torres, J. B.; Zanuncio, J. C. and Santos, G. P. (1998), Ciclo de vida e reprodução de Podisus distinctus (Stäl) (Heteroptera: Pentatomidae) alimentado com dois tipos de presas. Rev. Bras. Ent., 41, 335-337.

Zanuncio, J. C.; Zanuncio, T. V.; Guedes, R. N. C. and Ramalho, F. S. (2000), Effect of feeding on three Eucalyptus species on the development of Brontocoris tabidus (Het.: Pentatomidae) fed with Tenebrio molitor (Col.:Tenebrionidae). Bioc. Sci. Technol., 10, 443-450. 